\title{
Genetic Risk Factors for Perinatal Arterial Ischemic Stroke
}

\author{
Amy A. Gelfand, MD, Lisa A. Croen, PhD, Anthony R. Torres, MD, and Yvonne W. Wu, MD, \\ MPH \\ Departments of Neurology and Pediatrics [Y.W.W., A.A.G.], University of California, San \\ Francisco, San Francisco, CA, 94143, USA. Division of Research [L.A.C.], Kaiser Permanente, \\ Oakland, CA, 94612, USA. Department of Bioengineering and Center for Persons with Disabilities \\ [A.R.T.], Utah State University, Logan, UT, 84321
}

\begin{abstract}
The cause of perinatal arterial ischemic stroke is unknown in most cases. We explored whether genetic polymorphisms modify the risk of perinatal arterial ischemic stroke. In a population-based case-control study of 1997-2002 births at Kaiser Permanente Northern California, we identified 13 white infants with perinatal arterial ischemic stroke. Controls included 86 randomly selected white infants. We genotyped polymorphisms in 9 genes involved in inflammation, thrombosis or lipid metabolism that have been previously linked with stroke, and compared genotype frequencies in case and control individuals. We tested the following polymorphisms: TNF- $\mathrm{a}-308$, IL-6, lymphotoxin A, factor V Leiden, MTHFR 1298 and 667, prothrombin 20210, and apolipoprotein $\mathrm{E} \varepsilon 2$ and $\varepsilon 4$ alleles. Patients with perinatal arterial ischemic stroke were more likely than controls to have at least one apolipoprotein E $\varepsilon 4$ allele ( $54 \%$ vs. $25 \%, p=0.03)$. More patients with perinatal arterial ischemic stroke carried two $\varepsilon 4$ alleles than did controls (15\% vs. $2 \%, \mathrm{p}=0.09$ ), though this finding was not statistically significant. Proinflammatory and prothrombotic polymorphisms were not associated with perinatal arterial ischemic stroke in this small study. The apolipoprotein E polymorphism may confer genetic susceptibility for perinatal arterial ischemic stroke. Larger population-based studies are needed to confirm this finding.
\end{abstract}

\section{Keywords}

perinatal stroke; Apolipoprotein E

\section{Introduction}

Perinatal arterial ischemic stroke is a well recognized cause of cerebral palsy, epilepsy, and behavioral abnormalities in children[1]. By definition, perinatal arterial ischemic stroke occurs either in utero or before twenty-eight days of life, although infants may present in a delayed fashion later in infancy[1,2]. The incidence of perinatal arterial ischemic stroke is 20 per 100,000 live births, 17 times higher than the rate of childhood ischemic stroke and as high as the annual incidence of large vessel ischemic stroke in adults (17-23 per 100,000)[1,

\footnotetext{
(C) 2012 Elsevier Inc. All rights reserved.

Corresponding Author: Amy Gelfand, MD, UCSF Child Neurology, 350 Parnassus Ave, Suite 609, San Francisco, CA 94143-0137, GelfandA@ @europeds.ucsf.edu, Phone: (415) 353-3820, Fax: (415) 353-2400.

Financial disclosure: This study was funded by NIH K02 NS46688, the United Cerebral Palsy Foundation, and by the Cerebral Palsy Institute

Publisher's Disclaimer: This is a PDF file of an unedited manuscript that has been accepted for publication. As a service to our customers we are providing this early version of the manuscript. The manuscript will undergo copyediting, typesetting, and review of the resulting proof before it is published in its final citable form. Please note that during the production process errors may be discovered which could affect the content, and all legal disclaimers that apply to the journal pertain.
} 
3]. Previously identified risk factors for perinatal arterial ischemic stroke include primiparity, infertility, preeclampsia, prolonged rupture of membranes, emergency Cesarean delivery, chorioamnionitis, neonatal prothrombotic disorders and meningitis or other intracranial infections [3, 4]. However, the cause of perinatal arterial ischemic stroke is unknown in most cases[5].

Genetic susceptibility may play a role in the pathogenesis of perinatal stroke. For instance, studies have suggested that Factor V Leiden and MTHFR mutations may be associated with increased risk of perinatal stroke[6-8]. On the other hand, a study examining polymorphisms of genes involved in the regulation of thrombosis and thrombolysis, and genes related to nitric oxide, cytokines, blood pressure control and cell adhesion did not find any differences in patients with perinatal arterial ischemic stroke compared to controls[5].

Studies of ischemic stroke in adults have revealed several single nucleotide polymorphisms (SNPs) that modify an individual's risk of stroke[9-12]. Whether these polymorphisms are associated with risk of perinatal stroke is unknown. The objective of this case-control study was to explore whether genetic polymorphisms known to be associated with ischemic stroke in adults are also associated with risk of arterial ischemic stroke in newborn infants.

\section{Methods}

We performed a case-control study nested within the cohort of all 199,176 infants born from January 1, 1997, to December 31, 2002, in Kaiser Permanents of Northern California (KPNC). KPNC is a large integrated healthcare delivery system that provides care for approximately $30 \%$ of the population in northern California. The members of KPNC are demographically similar to the California population, except that the very poor and very wealthy are underrepresented[13]. All demographic data were obtained from medical record review. The study procedures were approved by the institutional review boards at KPNC, the University of California, San Francisco, Utah State University and the California Committee for the Protection of Human Subjects.

\section{Case and Control Identification}

The methodology used to identify the infants with perinatal arterial ischemic stroke has been described previously[3]. Perinatal arterial ischemic stroke was defined as stroke that occurred in utero or up to twenty-eight days after birth[3]. To identify infants with perinatal arterial ischemic stroke, we searched all brain magnetic resonance imaging (MRI) and computed tomographic (CT) reports of infants within the KPNC birth cohort for key words indicating possible perinatal arterial ischemic stroke [3]. The imaging studies were reviewed by a neuroradiologist to confirm the presence of an arterial-distribution ischemic infarction. Infants' with both acute stroke (neurologic presentation within first twenty-eight days of life) and presumed perinatal stroke (neurologic presentation after one month of age with imaging showing an old arterial-ischemic infarction) were included.

Given the heterogeneity in SNP frequencies among different ethnic groups[14, 15], genetic association studies typically restrict analyses to one ethnic group[16-18], or stratify by ethnicity[19]. We restricted our study to non-Hispanic white infants, since the small size of our study precluded meaningful analyses of other ethnic groups. Of the 37 infants identified with perinatal arterial ischemic stroke, the 13 white infants constituted the cases of this study. In a previous study, we randomly selected 165 healthy control infants born during the years 1991-2002 at Kaiser Permanente.[20] Among these previously described control infants, we selected the subset of all 86 non-Hispanic whites born during the current study period (1997-2002) as control infants for the current study. 


\section{Blood sample retrieval}

Our methods of blood sample collection and genomic DNA extraction have been described previously[17]. We retrieved stored neonatal blood specimens from the newborn screening specimen archives maintained by the California Department of Public Health. Dried blood spots have been stored on all infants born in California since 1980. Newborn blood specimens are collected on Guthrie card filter paper and dry at room temperature prior to submission for routine genetic and metabolic screening. Upon completion of the screening tests, remaining blood samples are stored at $-15^{\circ} \mathrm{C}$ in a single refrigerated warehouse[17].

\section{Genomic DNA Extraction from blood spots}

Blood spot Guthrie cards were punched with a 3-mm paper punch in a laminar flow hood under aseptic conditions. Two 3-mm punches from each subject were placed into a 96-well plate and incubated at $56^{\circ} \mathrm{C}$ for one hour in Qiagen buffer and Proteinase K enzyme. Genomic DNA was isolated from the blood spot punches using QIAamp 96 DNA blood kits supplied by Qiagen. The procedure for multiple displacement amplification (MDA) using Phi 29 polymerase was performed at $30^{\circ} \mathrm{C}$ for 16 hours using RepliPHI ${ }^{\mathrm{TM}}$ Phi 29 Reagent Sets (Epicentre ${ }^{\circledR}$ Technologies, Madison, Wisconsin) and stopped by inactivating the Phi 29 enzyme at $65^{\circ} \mathrm{C}$ in a water bath for 5 minutes. The amount of DNA extracted from two punches varied somewhat between samples, but there was an average of $235 \mathrm{ng}$ of genomic DNA from two $3.2 \mathrm{~mm}$ punches[17].

\section{SNP genotyping}

Standard Taqman PCR reactions were performed using an Applied Biosystems 7500 Fast system AB 96-well optical plates (plates P/N 4366932). The reactions were designed according to the Applied Biosystems SNP assay protocol in $10 \mu \mathrm{L}$ volumes. Each reaction was done in a single well due to limiting amounts of genomic DNA. Results from all experiments were obtained from Applied Biosystems SDS software v2.0 and Copy Caller software v1.0. All genotyping was performed blind to case status and clinical history[17]. We genotyped the following polymorphisms because they have been previously associated with ischemic stroke in adults: tumor necrosis factor-a (TNF-a) -308 G/A (rs1800629)[11, 12]; IL-6 -174 G/C (rs1800795)[18, 21, 22]; lymphotoxin C804A (rs1041981)[9]; factor V Leiden (FVL) 506 G/A (rs6025)[23, 24]; methyltetrahydrofolate reductase (MTHFR) 1298 $\mathrm{A} / \mathrm{C}$ (rs1801131)[25] and $667 \mathrm{C} / \mathrm{T}$ (rs1801133)[10, 25]; prothrombin $20210 \mathrm{G} / \mathrm{A}$ (rs1799963)[23, 24]; and apolipoprotein E (apoE) $\varepsilon 2$ and $\varepsilon 4$ alleles (rs429358 and rs7412) [10].

\section{Data analysis}

We defined SNP genotypes as follows: common homozygote $=$ two copies of the common allele; heterozygote $=$ one copy of each allele; and rare homozygote $=$ two copies of the rare allele. With logistic regression, we determined odds ratios (OR) and 95\% confidence intervals (CI) using two genetic models: 1) rare homozygote vs. common homozygote and 2) heterozygote or rare homozygote vs. common homozygote[17]. For the apolipoprotein E analysis, to be in keeping with other literature, we compared allelic frequency of the three apolipoprotein $\mathrm{E}$ alleles $(\varepsilon 2, \varepsilon 3$, and $\varepsilon 4)$ in cases versus controls. We performed chi-squared analyses, Fisher's exact tests and Student's t-test as appropriate, when comparing demographic variables in the case and control groups. We used logistic regression to compare continuous variables such as birth weight and gestational age. Given the small and exploratory nature of this study, we did not correct for multiple comparisons. Given the limited number of cases, multivariable analysis was not feasible. 


\section{Results}

Birth weight, infant sex and maternal age did not differ between the cases and controls (Table 1). Preeclampsia and chorioamnionitis rates also did not differ. However, infants with perinatal arterial ischemic stroke were slightly older (mean $40.1 \mathrm{vs.} 39.3$ weeks, $p=0.03$ ) and more likely than control infants to be born by Cesarean section ( $46 \%$ vs. $19 \%, p=0.03$ ). There was a trend for more primigravida mothers among case infants ( $75 \%$ vs. $46 \%$, $p=0.07)$. Neonatal seizures were present in five of the cases and none of the controls.

All SNP genotype distributions within the control population were in Hardy-Weinberg equilibrium (Table 2). The SNP genotype distributions for the cases are shown in Table 3. None of the proinflammatory or prothrombotic polymorphisms tested were significantly different between the two groups (Table 4).

Infants with perinatal arterial ischemic stroke were more likely than control infants to possess one or more apoE $\varepsilon 4$ allele ( $54 \%$ vs. $25 \%, p=0.03$ ). More patients with perinatal arterial ischemic stroke carried two $\varepsilon 4$ alleles than did controls ( $15 \%$ vs. $2 \%, p=0.09$ ), but this difference did not reach statistical significance (Table 5). Case infants were significantly less likely than control infants to have at least one $\varepsilon 3$ allele ( $69 \%$ vs. $94 \%, p=0.02$ ). The allelic frequencies for apolipoprotein $\mathrm{E}$ in both groups are shown in Table 6. Compared to control children, case children had significantly lower overall allelic frequency of $\varepsilon 3$ (54\% vs. $80 \%, p=0.006)$ and significantly higher allelic frequency of $\varepsilon 4$ ( $35 \%$ vs. $14 \%, p=0.02)$.

\section{Discussion}

In this exploratory study, the apolipoprotein $\mathrm{E} \varepsilon 4$ allele was associated with increased risk of perinatal arterial ischemic stroke. Although the apoE $\varepsilon 4$ allele has been linked to cerebral palsy[26, 27] and to adult stroke[10], this is the first study to our knowledge to explore the relationship between apoE and perinatal arterial ischemic stroke. perinatal arterial ischemic stroke is a relatively common cause of hemiplegic cerebral palsy[28]. Therefore, a relationship between the apoE $\varepsilon 4$ allele and perinatal arterial ischemic stroke could explain the previously reported increase in cerebral palsy rates among infants who carry this genetic variant.

Apolipoprotein E is a gene involved in lipid transport and metabolism and is highly expressed in the central nervous system[29, 30]. ApoE is secreted by astrocytes into the extracellular space, where it binds cholesterol. Neurons then take up the apoE so that cholesterol can be incorporated into cell membrane structures and myelin. These processes are critical in neurodevelopment as well as in neuronal repair after central nervous system injury[31-34]. ApoE may also play a role in regulating central nervous system inflammation[31,35].

ApoE has three alleles, $\varepsilon 2, \varepsilon 3$ and $\varepsilon 4$, yielding six possible genotypes. In most Caucasian populations the $\varepsilon 3$ allele is most common, appearing on more than $75 \%$ of chromosomes, making $\varepsilon 3 \varepsilon 3$ the most common genotype[29, 36, 37]. The $\varepsilon 2$ and $\varepsilon 4$ alleles have frequencies of $8 \%$ and $15 \%$ respectively[36-38] in white populations, which is similar to the $6 \%$ and $14 \%$ allelic frequencies found in our control population. The $\varepsilon 4$ form binds preferentially to triglyceride rich lipoproteins such as very low-density lipoproteins, while the other isoforms have a higher affinity for high-density lipoproteins[38, 39].

In adults, the $\varepsilon 4$ isoform is strongly associated with sporadic Alzheimer disease, cognitive decline and atherosclerotic cardiovascular disease[36, 40, 41], while the $\varepsilon 2$ allele is typically viewed as protective. Ischemic stroke risk is increased in adults with an $\varepsilon 4$ allele, with odds ratios ranging from 1.1 to $2.5[10,29,42]$. In addition, neurologic outcomes after 
subarachnoid hemorrhage, traumatic brain injury, and intra-cerebral hemorrhage are worse in adults who have an $\varepsilon 4$ allele[33, 43-46].

The effect of the apoE $\varepsilon 4$ allele may be different in neonates compared to adults. The presence of an $\varepsilon 4$ allele in the fetus appears to protect against spontaneous miscarriage (OR 0.3, 95\% CI 0.1-0.8)[39]. Healthy Scottish newborns are more likely to have an $\varepsilon 4$ allele than stillborn infants (OR 1.6, 95\% CI 1.1-2.3), though the $\varepsilon 4$ allele did not protect against post-natal perinatal death[47]. Despite these possible benefits, the $\varepsilon 4$ allele may confer increased risk for other perinatal complications. For instance, the $\varepsilon 4$ allele has been associated with cerebral palsy in most[10, 26, 27, 42, 48, 49], but not all studies[29, 50]. In addition, maternal carriage of $\varepsilon 4$ is associated with recurrent pregnancy loss [49, 51-55].

ApoE is expressed by fetal genes in the placenta, where it is thought to play an active role in the metabolism of maternal lipoproteins[56, 57]. It has been hypothesized that some cases of perinatal arterial ischemic stroke may result from an embolic clot originating from the placenta[58-61]. The $\varepsilon 4$ allele has a higher binding affinity for low density lipoproteins compared to the other isoforms[38]. Whether placental clots may be more likely to arise in the presence of an apoE $\varepsilon 4$ allele because of altered placental lipoprotein metabolism is unknown.

We did not find an association between the apoE $\varepsilon 2$ allele and perinatal arterial ischemic stroke. However, in one study the e2 allele was associated with cerebral palsy[26], and it has also been associated with worse behavioral outcomes in young children[62]. More research is needed to determine if the $\mathrm{e} 2$ allele has implications for early-life neurologic outcomes.

Previous studies have suggested that genetic thrombophilias may increase the risk of perinatal arterial ischemic stroke[6, 7,24], though not all studies have supported this notion [5, 63]. Given our small sample size, it is likely we were underpowered to detect anything other than large-magnitude associations. Therefore, given potential Type 2 error, we are unable to rule out an association between perinatal arterial ischemic stroke and the other SNP's that we studied. We included the SNP genotype frequencies from our cases in Table 3 so that they can be included in future meta-analysis studies that might have higher power. Given this was a small exploratory study, we elected not to correct for multiple comparisons.

\section{Conclusion}

In our cohort, the apoE $\varepsilon 4$ allele was more frequent in those with perinatal arterial ischemic stroke versus controls. Other polymorphisms in our study were not associated with perinatal arterial ischemic stroke, though the study had limited power. More large population based studies are needed to further investigate the potential association between ApoE $\varepsilon 4$ and perinatal arterial ischemic stroke.

\section{Acknowledgments}

The authors would like to thank Judy Grether, Martin Kharrazi and Steven Graham for their assistance with blood spot retrieval. We also gratefully acknowledge Andrew Van de Werf, who performed the Taqman typing. We would like to thank Dr. Heather Fullerton for her helpful comments on an earlier version of the manuscript.

\section{Abbreviations}

$\begin{array}{ll}\text { PAS } & \text { perinatal arterial stroke } \\ \text { CP } & \text { cerebral palsy }\end{array}$




\section{References}

1. Lee J, Croen LA, Lindan C, Nash KB, Yoshida CK, Ferriero DM, Barkovich AJ, Wu YW. Predictors of outcome in perinatal arterial stroke: a population-based study. Ann Neurol. 2005; 58:303-8. [PubMed: 16010659]

2. Raju TN, Nelson KB, Ferriero D, Lynch JK. Ischemic perinatal stroke: summary of a workshop sponsored by the National Institute of Child Health and Human Development and the National Institute of Neurological Disorders and Stroke. Pediatrics. 2007; 120:609-16. [PubMed: 17766535]

3. Lee J, Croen LA, Backstrand KH, Yoshida CK, Henning LH, Lindan C, Ferriero DM, Fullerton HJ, Barkovich AJ, Wu YW. Maternal and infant characteristics associated with perinatal arterial stroke in the infant. JAMA. 2005; 293:723-9. [PubMed: 15701914]

4. Wu YW, Lynch JK, Nelson KB. Perinatal arterial stroke: understanding mechanisms and outcomes. Semin Neurol. 2005; 25:424-34. [PubMed: 16341998]

5. Miller SP, Wu YW, Lee J, Lammer EJ, Iovannisci DM, Glidden DV, Bonifacio SL, Collins A, Shaw GM, Barkovich AJ, Ferriero DM. Candidate gene polymorphisms do not differ between newborns with stroke and normal controls. Stroke. 2006; 37:2678-83. [PubMed: 17008620]

6. Mercuri E, Cowan F, Gupte G, Manning R, Laffan M, Rutherford M, Edwards AD, Dubowitz L, Roberts I. Prothrombotic disorders and abnormal neurodevelopmental outcome in infants with neonatal cerebral infarction. Pediatrics. 2001; 107:1400-4. [PubMed: 11389264]

7. Hagstrom JN, Walter J, Bluebond-Langner R, Amatniek JC, Manno CS, High KA. Prevalence of the factor V leiden mutation in children and neonates with thromboembolic disease. J Pediatr. 1998; 133:777-81. [PubMed: 9842043]

8. Del Balzo F, Spalice A, Ruggieri M, Greco F, Properzi E, Iannetti P. Stroke in children: inherited and acquired factors and age-related variations in the presentation of 48 paediatric patients. Acta Paediatr. 2009; 98:1130-6. [PubMed: 19432826]

9. Trompet S, de Craen AJ, Slagboom P, Shepherd J, Blauw GJ, Murphy MB, Bollen EL, Buckley BM, Ford I, Gaw A, Macfarlane PW, Packard CJ, Stott DJ, Westendorp RG, Jukema JW. Lymphotoxin-alpha C804A polymorphism is a risk factor for stroke. The PROSPER study. Exp Gerontol. 2008; 43:801-5. [PubMed: 18504081]

10. Xin XY, Song YY, Ma JF, Fan CN, Ding JQ, Yang GY, Chen SD. Gene polymorphisms and risk of adult early-onset ischemic stroke: A meta-analysis. Thromb Res. 2009; 124:619-24. [PubMed: 19660787]

11. Rubattu S, Speranza R, Ferrari M, Evangelista A, Beccia M, Stanzione R, Assenza GE, Volpe M, Rasura M. A role of TNF-alpha gene variant on juvenile ischemic stroke: a case-control study. Eur J Neurol. 2005; 12:989-93. [PubMed: 16324093]

12. Hoppe C, Klitz W, D’Harlingue K, Cheng S, Grow M, Steiner L, Noble J, Adams R, Styles L. Confirmation of an association between the TNF(-308) promoter polymorphism and stroke risk in children with sickle cell anemia. Stroke. 2007; 38:2241-6. [PubMed: 17600229]

13. Krieger N. Overcoming the absence of socioeconomic data in medical records: validation and application of a census-based methodology. Am J Public Health. 1992; 82:703-10. [PubMed: 1566949]

14. Das K, Das MK, Mastana SS. Genetic diversity of serum proteins in three subpopulations of the Maria Gond tribe of Madhya Pradesh, India. Anthropol Anz. 2003; 61:261-8. [PubMed: 14523999]

15. Roberts LN, Patel RK, Arya R. Venous thromboembolism and ethnicity. Br J Haematol. 2009; 146:369-83. [PubMed: 19552721]

16. Ramos EM, Lin MT, Larson EB, Maezawa I, Tseng LH, Edwards KL, Schellenberg GD, Hansen JA, Kukull WA, Jin LW. Tumor necrosis factor alpha and interleukin 10 promoter region polymorphisms and risk of late-onset Alzheimer disease. Arch Neurol. 2006; 63:1165-9. [PubMed: 16908746] 
17. Wu YW, Croen LA, Vanderwerf A, Gelfand AA, Torres AR. Candidate genes and risk for CP: a population-based study. Pediatr Res. 2011; 70:642-6. [PubMed: 21857382]

18. Stoica AL, Stoica E, Constantinescu I, Uscatescu V, Ginghina C. Interleukin-6 and interleukin-10 gene polymorphism, endothelial dysfunction, and postoperative prognosis in patients with peripheral arterial disease. J Vasc Surg. 2010; 52:103-9. [PubMed: 20385468]

19. Kaiser R, Li Y, Chang M, Catanese J, Begovich AB, Brown EE, Edberg JC, McGwin G Jr, Alarcon GS, Ramsey-Goldman R, Reveille JD, Vila LM, Petri MA, Kimberly RP, Taylor KE, Criswell LA. Genetic risk factors for thrombosis in systemic lupus erythematosus. J Rheumatol. 2012; 39:1603-10. [PubMed: 22707612]

20. Wu YW, Croen LA, Torres AR, Van De Water J, Grether JK, Hsu NN. Interleukin-6 genotype and risk for cerebral palsy in term and near-term infants. Ann Neurol. 2009; 66:663-70. [PubMed: 19938160]

21. Manso H, Krug T, Sobral J, Albergaria I, Gaspar G, Ferro JM, Oliveira SA, Vicente AM. Variants in the inflammatory IL6 and MPO genes modulate stroke susceptibility through main effects and gene-gene interactions. J Cereb Blood Flow Metab. 2011 Mar 16.

22. Manso H, Krug T, Sobral J, Albergaria I, Gaspar G, Ferro JM, Oliveira SA, Vicente AM. Variants in the inflammatory IL6 and MPO genes modulate stroke susceptibility through main effects and gene-gene interactions. J Cereb Blood Flow Metab. 2011; 31:1751-9. [PubMed: 21407237]

23. Casas JP, Hingorani AD, Bautista LE, Sharma P. Meta-analysis of genetic studies in ischemic stroke: thirty-two genes involving approximately 18,000 cases and 58,000 controls. Arch Neurol. 2004; 61:1652-61. [PubMed: 15534175]

24. Kenet G, Lutkhoff LK, Albisetti M, Bernard T, Bonduel M, Brandao L, Chabrier S, Chan A, deVeber G, Fiedler B, Fullerton HJ, Goldenberg NA, Grabowski E, Gunther G, Heller C, Holzhauer S, Iorio A, Journeycake J, Junker R, Kirkham FJ, Kurnik K, Lynch JK, Male C, MancoJohnson M, Mesters R, Monagle P, van Ommen CH, Raffini L, Rostasy K, Simioni P, Strater RD, Young G, Nowak-Gottl U. Impact of thrombophilia on risk of arterial ischemic stroke or cerebral sinovenous thrombosis in neonates and children: a systematic review and meta-analysis of observational studies. Circulation. 2010; 121:1838-47. [PubMed: 20385928]

25. Rook JL, Nugent DJ, Young G. Pediatric stroke and methylenetetrahydrofolate reductase polymorphisms: an examination of C677T and A1298C mutations. J Pediatr Hematol Oncol. 2005; 27:590-3. [PubMed: 16282888]

26. Kuroda MM, Weck ME, Sarwark JF, Hamidullah A, Wainwright MS. Association of apolipoprotein E genotype and cerebral palsy in children. Pediatrics. 2007; 119:306-13. [PubMed: 17272620]

27. Meirelles Kalil Pessoa de B, Rodrigues CJ, de Barros TE, Bevilacqua RG. Presence of apolipoprotein E epsilon4 allele in cerebral palsy. J Pediatr Orthop. 2000; 20:786-9. [PubMed: 11097255]

28. Wu YW, Lindan CE, Henning LH, Yoshida CK, Fullerton HJ, Ferriero DM, Barkovich AJ, Croen LA. Neuroimaging abnormalities in infants with congenital hemiparesis. Pediatr Neurol. 2006; 35:191-6. [PubMed: 16939859]

29. Sudlow C, Martinez Gonzalez NA, Kim J, Clark C. Does apolipoprotein E genotype influence the risk of ischemic stroke, intracerebral hemorrhage, or subarachnoid hemorrhage? Systematic review and meta-analyses of 31 studies among 5961 cases and 17,965 controls. Stroke. 2006; 37:364-70. [PubMed: 16385096]

30. Balcerzyk A, Zak I, Niemiec P, Kopyta I, Emich-Widera E, Iwanicki T, Pilarska E, PienczkReclawowicz K, Kacinski M, Wendorff J, Jachowicz-Jeszka J. APOE gene epsilon polymorphism does not determine predisposition to ischemic stroke in children. Pediatr Neurol. 2010; 43:25-8. [PubMed: 20682199]

31. Braga LW, Borigato EV, Speck-Martins CE, Imamura EU, Gorges AM, Izumi AP, Dantas RC, Nunes LG. Apolipoprotein E genotype and cerebral palsy. Dev Med Child Neurol. 2010; 52:66671. [PubMed: 20002130]

32. Xu Q, Bernardo A, Walker D, Kanegawa T, Mahley RW, Huang Y. Profile and regulation of apolipoprotein $\mathrm{E}$ (ApoE) expression in the CNS in mice with targeting of green fluorescent protein gene to the ApoE locus. J Neurosci. 2006; 26:4985-94. [PubMed: 16687490] 
33. Lanterna LA, Biroli F. Significance of apolipoprotein E in subarachnoid hemorrhage: neuronal injury, repair, and therapeutic perspectives--a review. J Stroke Cerebrovasc Dis. 2009; 18:116-23. [PubMed: 19251187]

34. Wright RO, Hu H, Silverman EK, Tsaih SW, Schwartz J, Bellinger D, Palazuelos E, Weiss ST, Hernandez-Avila M. Apolipoprotein E genotype predicts 24-month bayley scales infant development score. Pediatr Res. 2003; 54:819-25. [PubMed: 12930912]

35. Laskowitz DT, Matthew WD, Bennett ER, Schmechel D, Herbstreith MH, Goel S, McMillian MK. Endogenous apolipoprotein E suppresses LPS-stimulated microglial nitric oxide production. Neuroreport. 1998; 9:615-8. [PubMed: 9559926]

36. Farrer LA, Cupples LA, Haines JL, Hyman B, Kukull WA, Mayeux R, Myers RH, Pericak-Vance MA, Risch N, van Duijn CM. Effects of age, sex, and ethnicity on the association between apolipoprotein E genotype and Alzheimer disease. A meta-analysis. APOE and Alzheimer Disease Meta Analysis Consortium. JAMA. 1997; 278:1349-56. [PubMed: 9343467]

37. Zannis VI, Kardassis D, Zanni EE. Genetic mutations affecting human lipoproteins, their receptors, and their enzymes. Adv Hum Genet. 1993; 21:145-319. [PubMed: 8391199]

38. Mahley RW, Rall SC Jr. Is epsilon4 the ancestral human apoE allele? Neurobiol Aging. 1999; 20:429-30. [PubMed: 10604434]

39. Zetterberg H, Palmer M, Ricksten A, Poirier J, Palmqvist L, Rymo L, Zafiropoulos A, Arvanitis DA, Spandidos DA, Blennow K. Influence of the apolipoprotein E epsilon4 allele on human embryonic development. Neurosci Lett. 2002; 324:189-92. [PubMed: 12009520]

40. Davignon J, Bouthillier D, Nestruck AC, Sing CF. Apolipoprotein E polymorphism and atherosclerosis: insight from a study in octogenarians. Trans Am Clin Climatol Assoc. 1988; 99:100-10. [PubMed: 3503432]

41. Davignon J, Gregg RE, Sing CF. Apolipoprotein E polymorphism and atherosclerosis. Arteriosclerosis. 1988; 8:1-21. [PubMed: 3277611]

42. McCarron MO, Delong D, Alberts MJ. APOE genotype as a risk factor for ischemic cerebrovascular disease: a meta-analysis. Neurology. 1999; 53:1308-11. [PubMed: 10522889]

43. Teasdale GM, Nicoll JA, Murray G, Fiddes M. Association of apolipoprotein E polymorphism with outcome after head injury. Lancet. 1997; 350(9084):1069-71. [PubMed: 10213549]

44. Friedman G, Froom P, Sazbon L, Grinblatt I, Shochina M, Tsenter J, Babaey S, Yehuda B, Groswasser Z. Apolipoprotein E-epsilon4 genotype predicts a poor outcome in survivors of traumatic brain injury. Neurology. 1999; 52:244-8. [PubMed: 9932938]

45. Martinez-Gonzalez NA, Sudlow CL. Effects of apolipoprotein E genotype on outcome after ischaemic stroke, intracerebral haemorrhage and subarachnoid haemorrhage. J Neurol Neurosurg Psychiatry. 2006; 77:1329-35. [PubMed: 16926234]

46. Gallek MJ, Conley YP, Sherwood PR, Horowitz MB, Kassam A, Alexander SA. APOE genotype and functional outcome following aneurysmal subarachnoid hemorrhage. Biol Res Nurs. 2009; 10:205-12. [PubMed: 19017669]

47. Becher JC, Keeling JW, McIntosh N, Wyatt B, Bell J. The distribution of apolipoprotein E alleles in Scottish perinatal deaths. J Med Genet. 2006; 43:414-8. [PubMed: 16183800]

48. Wang B, Zhao H, Zhou L, Dai X, Wang D, Cao J, Niu W. Association of genetic variation in apolipoprotein $\mathrm{E}$ and low density lipoprotein receptor with ischemic stroke in Northern Han Chinese. J Neurol Sci. 2009; 276:118-22. [PubMed: 18851860]

49. Wu D, Zou YF, Xu XY, Feng XL, Yang L, Zhang GC, Bu XS, Tang JL. The association of genetic polymorphisms with cerebral palsy: a meta-analysis. Dev Med Child Neurol. 2011; 53:217-25. [PubMed: 21291465]

50. McMichael GL, Gibson CS, Goldwater PN, Haan EA, Priest K, Dekker GA, MacLennan AA. Association between Apolipoprotein E genotype and cerebral palsy is not confirmed in a Caucasian population. Hum Genet. 2008; 124:411-6. [PubMed: 18810496]

51. Goodman C, Coulam C, Jeyendran RS. Association of apolipoprotein E polymorphisms and recurrent pregnancy loss. Fertil Steril. 2010; 93:e19. author reply e21. [PubMed: 20117776]

52. Bianca S, Barrano B, Cutuli N, Indaco L, Cataliotti A, Milana G, Barone C, Ettore G. No association between apolipoprotein E polymorphisms and recurrent pregnancy loss. Fertil Steril. 2010; 93:276. [PubMed: 19732892] 
53. Agarwal M, Parveen F, Faridi RM, Phadke SR, Das V, Agrawal S. Recurrent pregnancy loss and apolipoprotein $\mathrm{E}$ gene polymorphisms: a case-control study from north India. Am J Reprod Immunol. 2010; 64:172-8. [PubMed: 20560916]

54. Zhang HL, Mao XJ, Yang Y, Wu J. Recurrent pregnancy loss and apolipoprotein e gene polymorphisms. Am J Reprod Immunol. 2011; 65:395-6. [PubMed: 20825376]

55. Zhang HL, Wu J. Apolipoprotein E4 allele and recurrent pregnancy loss: is it time to draw a conclusion? Fertil Steril. 2010; 93:e20. author reply e1. [PubMed: 20117770]

56. Francoual J, Audibert F, Claise C, Chalas J, Trioche P, Frydman R, Lindenbaum A. Implication of apolipoprotein $\mathrm{E}$ and the L-arginine-nitric oxide system in preeclampsia. Hypertens Pregnancy. 1999; 18:229-37. [PubMed: 10586526]

57. Descamps OS, Bruniaux M, Guilmot PF, Tonglet R, Heller FR. Lipoprotein metabolism of pregnant women is associated with both their genetic polymorphisms and those of their newborn children. J Lipid Res. 2005; 46:2405-14. [PubMed: 16106048]

58. Ghidini A, Locatelli A. Diffuse placental chorioangiomatosis causing multiple fetal cerebral embolism: a case report. J Reprod Med. 2006; 51:321-4. [PubMed: 16737029]

59. Case records of the Massachusetts General Hospital. Weekly clinicopathological exercises. Case 15-1997. Respiratory distress and seizure in a neonate. N Engl J Med. 1997; 336:1439-46. [PubMed: 9145683]

60. Barmada MA, Moossy J, Shuman RM. Cerebral infarcts with arterial occlusion in neonates. Ann Neurol. 1979; 6:495-502. [PubMed: 533248]

61. Kraus FT, Acheen VI. Fetal thrombotic vasculopathy in the placenta: cerebral thrombi and infarcts, coagulopathies, and cerebral palsy. Hum Pathol. 1999; 30:759-69. [PubMed: 10414494]

62. Gaynor JW, Nord AS, Wernovsky G, Bernbaum J, Solot CB, Burnham N, Zackai E, Heagerty PJ, Clancy RR, Nicolson SC, Jarvik GP, Gerdes M. Apolipoprotein E genotype modifies the risk of behavior problems after infant cardiac surgery. Pediatrics. 2009; 124:241-50. [PubMed: 19564306]

63. Laugesaar R, Kahre T, Kolk A, Uustalu U, Kool P, Talvik T. Factor V Leiden and prothrombin 20210G >A [corrected] mutation and paediatric ischaemic stroke: a case-control study and two meta-analyses. Acta Paediatr. 2010; 99:1168-74. [PubMed: 20337781] 


\section{Table 1}

Association between clinical factors and perinatal arterial ischemic stroke.

\begin{tabular}{lccc}
\hline & Cases $(\mathbf{n = 1 3})$ & Controls (n=86) & $\boldsymbol{p}$-value \\
\hline Male & $77 \%$ & $55 \%$ & 0.22 \\
Maternal age (years); mean (SD) & $28(6.6)$ & $28.6(5.8)$ & 0.73 \\
Birth weight (grams); mean (SD) ${ }^{*}$ & $3561(485)$ & $3498(529)$ & 0.69 \\
Gestational age (weeks); mean (SD) ${ }^{* *}$ & $40.1(0.9)$ & $39.3(1.4)$ & 0.03 \\
Cesarean section ${ }^{* * *}$ & $46 \%$ & $19 \%$ & 0.03 \\
Primagravida ${ }^{*}+$ & $75 \%$ & $46 \%$ & 0.07 \\
Preeclampsia & $8 \%$ & $4 \%$ & 0.44 \\
Chorioamnionitis ${ }^{*},{ }^{*}$ & $10 \%$ & $5 \%$ & 0.43 \\
\hline$*$ \\
Data missing on one control infant;
\end{tabular}




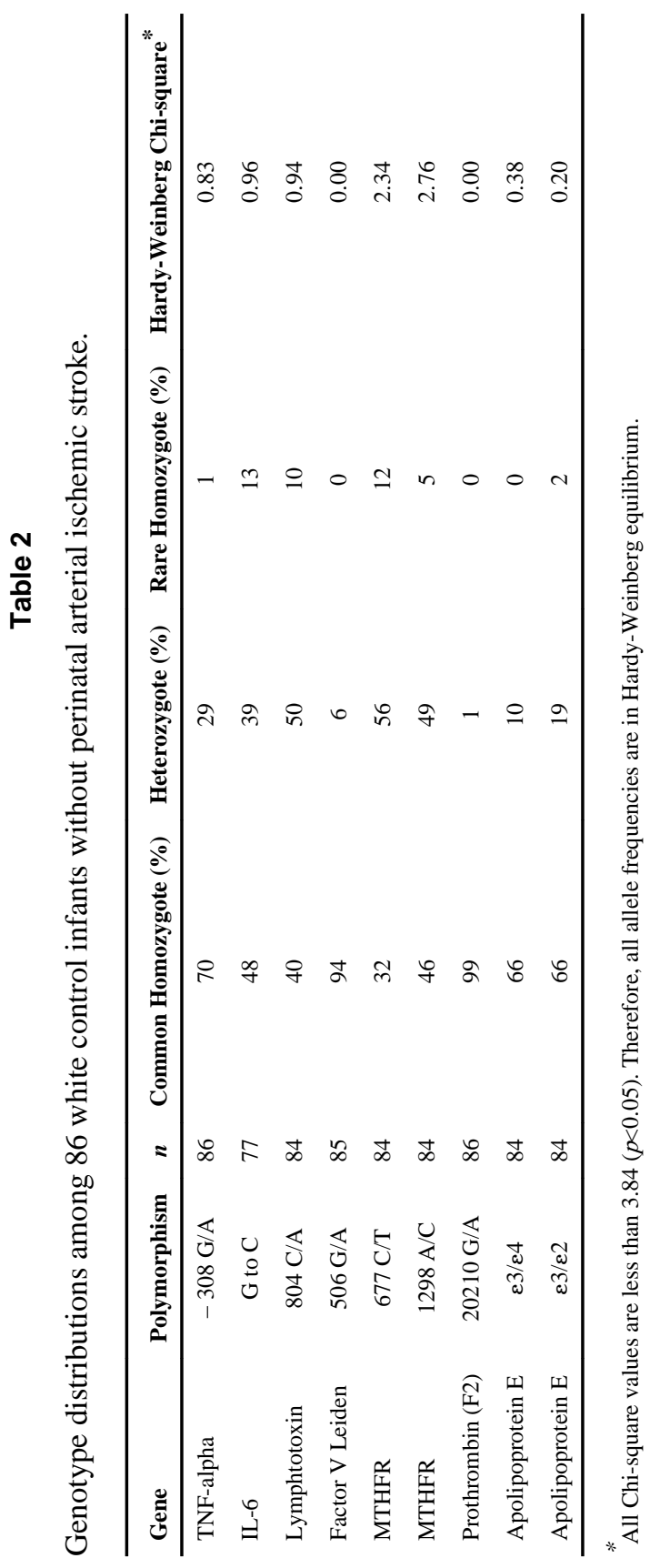




\section{Table 4}

Associations between polymorphisms in inflammatory and thrombotic genes, and perinatal arterial stroke.

\begin{tabular}{lcc}
\hline Gene (codon) & Rare homozygote or heterozygote vs. common homozygote & Rare homozygote vs. common homozygote \\
\hline Inflammatory & & \\
\hline TNF-alpha (-308) & OR $0.7(0.2-2.7)$ & NA \\
IL-6 (-174) & OR $1.5(0.4-4.9)$ & NA \\
Lymphtotoxin (804) & OR $1.1(0.3-3.6)$ & OR $0.9(0.1-8.3)$ \\
Thrombotic & & \\
Factor V Leiden (506) & NA & NA \\
MTHFR (677) & OR 2.0 (0.6-6.8) & OR 4.9 $(0.7-35.5)$ \\
MTHFR (1298) & OR $0.4(0.1-1.3)$ & OR $0.4(0.04-3.5)$ \\
Prothrombin (20210) & NA & NA \\
\hline
\end{tabular}

$\mathrm{OR}=$ odds ratio; NA=Not applicable; (the rare genotype was not present in any patients with perinatal arterial ischemic stroke); therefore, odds ratios could not be calculated. 
Table 5

Apolipoprotein E allele frequencies in infants with perinatal arterial ischemic stroke and controls.

\begin{tabular}{lccc}
\hline & Case $(\boldsymbol{n}=\mathbf{1 3}) \%$ & Control $(\boldsymbol{n}=\mathbf{8 4}){ }^{*} \%$ & $\boldsymbol{p}$-value \\
\hline Number of $\varepsilon$ 2 alleles: & & & \\
0 & 77 & 87 & 0.39 \\
1 & 23 & 13 & 0.39 \\
2 & 0 & 0 & 1.00 \\
Number of $\varepsilon$ 3 alleles & & & \\
0 & 31 & 6 & 0.02 \\
1 & 31 & 29 & 1.00 \\
2 & 39 & 66 & 0.07 \\
Number of $\varepsilon 4$ alleles: & & & \\
0 & 46 & 75 & 0.03 \\
1 & 39 & 23 & 0.3 \\
2 & 15 & 2 & 0.09 \\
* & & &
\end{tabular}




\section{Table 6}

Apolipoprotein E allele frequencies (\%) in infants with perinatal arterial ischemic stroke and controls

\begin{tabular}{cccc}
\hline & Case $(\boldsymbol{n = 1 3 )}$ & Control $\left(\boldsymbol{n = 8 4}{ }^{*}\right)$ & $\boldsymbol{p}$-value \\
\hline$\varepsilon 4$ & 35 & 14 & 0.02 \\
$\varepsilon 3$ & 54 & 80 & 0.006 \\
$\varepsilon 2$ & 11 & 6 & 0.39 \\
\hline
\end{tabular}

* Apolipoprotein E genotypes were unavailable for two control infants 